\title{
Hepatic Hyperplasia Associated with Discordant Xenogeneic Parenchymal-Nonparenchymal Interactions in Human Hepatocyte-Repopulated Mice
}

\author{
Rie Utoh, ${ }^{* \dagger}$ Chise Tateno, ${ }^{* £ \S}$ Miho Kataoka, ${ }^{*}$ \\ Asato Tachibana, ${ }^{\star \S}$ Norio Masumoto, ${ }^{* \pi}$ \\ Chihiro Yamasaki, ${ }^{\star \S}$ Takashi Shimada, ${ }^{\S}$ \\ Toshiyuki Itamoto, "T Toshimasa Asahara, ${ }^{\text {"ा }}$ \\ and Katsutoshi Yoshizato*£\&\|** \\ From the Yoshizato Project, Cooperative Link of Unique Science \\ and Technology for Economy Revitalization (CLUSTER),* \\ Hiroshima Prefectural Institute of Industrial Science and \\ Technology, Hiroshima; the Institute of Advanced Biomedical \\ Engineering and Science, ${ }^{\dagger}$ Tokyo Women's Medical University, \\ Tokyo; the Hiroshima University Liver Project Research Center, ${ }^{*}$ \\ Hiroshima; PhoenixBio Co., ${ }^{\S}$ Hiroshima; the Department of \\ Surgery, ${ }^{\pi}$ Division of Frontier Medical Science, Graduate School \\ of Biomedical Sciences, Hiroshima University, Hiroshima; Liver \\ Research Center," Osaka City University Graduate School of \\ Medicine, Osaka; and the Department of Biological Science,*** \\ Developmental Biology Laboratory and Hiroshima University 21st \\ Century COE Program for Advanced Radiation Casualty \\ Medicine, Graduate School of Science, Hiroshima University, \\ Hiroshima, Japan
}

Liver mass is optimized in relation to body mass. Rat (r) and human (h) hepatocytes were transplanted into liver-injured immunodeficient mice and allowed to proliferate for 3 or 11 weeks, respectively, when the transplants stopped proliferating. Liver/body weight ratio was normal throughout in r-hepatocytebearing mice (r-hep-mice), but increased continuously in h-hepatocyte-bearing mice (h-hep-mice), until reaching approximately three times the normal m-liver size, which was considered to be hyperplasia of $h$-hepatocytes because there were no significant differences in cell size among host (mouse [m-]) and donor (r- and h-) hepatocytes. Transforming growth factor- $\beta$ (TGF- $\beta$ ) type I receptor, TGF- $\beta$ type II receptor, and activin A type IIA receptor mRNAs in proliferating $\mathbf{r}$-hepatocytes of $\mathbf{r}$-hep-mice were lower than in resting $r$-hepatocytes (normal levels) and increased to normal levels during the termination phase. Concomitantly, m-hepatic stellate cells began to express TGF- $\beta$ proteins. In stark contrast, TGF- $\beta$ type II receptor and activin A type IIA receptor mRNAs in h-hepa- tocytes remained low throughout and $m$-hepatic stellate cells did not express TGF- $\beta$ in h-hep-mice. As expected, Smad2 and 3 translocated into nuclei in r-hep-mice but not in h-hep-mice. Histological analysis showed a paucity of $\mathrm{m}$-stellate cells in $\mathrm{h}$-hepatocyte colonies of h-hep-mouse liver. We conclude that m-stellate cells are able to normally interact with concordant r-hepatocytes but not with discordant h-hepatocytes, which seems to be at least partly responsible for the failure of the liver size optimization in h-hep-mice. (Am J Pathol 2010, 177:654-665; DOI: 10.2353/ajpath.2010.090430)

Experiments using animal models with damaged livers have demonstrated the high replicative potential of hepatocytes. A transgenic (Tg) mouse carrying an albumin (Alb) enhancer/promoter-driven murine urokinase-type plasminogen activator (UPA) gene was created ${ }^{1}$; the liver of this mouse degenerates and increases hepatocyte growth factor production and induces the proliferation of normal hepatocytes. ${ }^{2}$ When transplanted into the uPA-Tg mice, mouse $(\mathrm{m})$ hepatocytes engrafted into the host liver and proliferated, eventually replacing the host hepatocytes with a replacement index $(\mathrm{RI})$ of $80 \%,{ }^{3}$ where $\mathrm{RI}$ represents the ratio of the regions occupied by transplanted hepatocytes in the host liver). The offspring generated by crossing uPA-Tg mice with immunodeficient mice were used as hosts for the xenotransplantation of rat (r), ${ }^{4}$ woodchuck, ${ }^{5}$ and human (h) hepatocytes. ${ }^{6-8}$

We showed that the repopulation kinetics of $r$-hepatocytes in uPA/severe combined immunodeficiency (SCID) mice were different from those of h-hepatocytes. ${ }^{9}$ Rat

Supported in part by Cooperative Link of Unique Science and Technology for Economy Revitalization (CLUSTER), Promotion of Science and Technology in Regional Areas, Ministry of Education, Culture, Sports, Science and Technology, Japan.

Accepted for publication March 30, 2010.

None of the authors declare any relevant financial relationships.

Address reprint requests to Katsutoshi Yoshizato, Ph.D., PhoenixBio Co., Ltd., 3-4-1 Kagamiyama, Higashihiroshima, Hiroshima 739-0046, Japan. E-mail: katsutoshi.yoshizato@phoenixbio.co.jp. 
hepatocytes rapidly proliferated and completely repopulated the mouse liver, whereas h-hepatocytes proliferated slowly over a longer period, with $\mathrm{RI}=\sim 90 \%$. However, the livers of mice bearing h-hepatocytes (h-hep-mice) became much larger than the normal mass of the host mouse liver as the RI increased, whereas their counterparts with r-hepatocytes (r-hep-mice) did not (unpublished data). The above result with h-hep-mice does not meet the empirical rule (liver size optimization rule) that liver size is determined by the size of an animal's body. ${ }^{10}$ This rule says that livers from smaller animals transplanted to larger animals must increase in size, which has been demonstrated in dogs, ${ }^{10}$ humans, ${ }^{11}$ and rats. ${ }^{12}$

Transforming growth factor (TGF)- $\beta^{13,14}$ and activin ${ }^{15}$ are potent inhibitors of hepatocyte proliferation. The initiation of TGF- $\beta$ signaling requires binding to the TGF- $\beta$ type II receptor (TGFBR2), a constitutively active serinethreonine kinase, which subsequently trans-phosphorylates TGF- $\beta$ type I receptor (TGFBR1). Activated TGFBR1 phosphorylates the Smad family proteins, Smad2 and 3 (Smad2/3), which then complex with Smad4 and translocate into the nucleus. ${ }^{16}$ Smad2/3 are also activated by activin and nodal receptors, members of the TGF- $\beta$ superfamily. ${ }^{17}$ After partial hepatectomy, TGF- $\beta$ mRNA expression increased in nonparenchymal cells, and TGF- $\beta$ seemed to function as an inhibitory paracrine factor to prevent uncontrolled hepatocyte growth. ${ }^{18}$

When hepatocyte-targeted TGFBR2-knockout (KO) mice were subjected to $70 \%$ partial hepatectomy, hepatocytes grew beyond the limit of the known liver/body weight ratio $\left(R_{L / B}\right){ }^{19}$ supporting the antiproliferative role of TGF- $\beta$ signaling. However, a similar study with hepatocyte-targeted TGFBR2-KO mice showed no significant differences in $R_{L / B}$ between control and $K O$ mice because of an alternative increase in signaling via activin A/activin A type IIA receptor (ACVR2A) and persistent Smad pathway activity. ${ }^{20}$ Thus, the roles of TGF- $\beta$, activin, and their receptors in the regulation of liver mass remain to be further studied.

In the present study, we compared the repopulation processes of concordant (rat) and discordant (human) xenogeneic hepatocytes in the UPA/SCID mouse liver. Our results showed that $r$-hep-mice had normal mouse regulation of $R_{L / B}$, whereas h-hep-mice underwent liver hyperplasia, resulting in the increase in $R_{L / B}$. The present study strongly suggests that discordant $\mathrm{h}$-hepatocytes fail in exchanging molecular signals including TGF- $\beta$ / activin with $\mathrm{m}$-hepatic stellate cell (HSCs) and proliferate over the liver size optimization rule for mouse.

\section{Materials and Methods}

\section{Preparation of Liver Tissues and Hepatocytes}

The Hiroshima Prefectural Institute of Industrial Science and Technology Ethics Board approved this study. Liver tissues were obtained from seven donors in hospitals, with informed consent before the operations in accordance with the 1975 Declaration of Helsinki: four males, a 12-year-old male (12YM), a 28-year-old male (28YM), a 49-year-old male (49YM), and a 50-year-old male (50YM), and three females, a 25-year-old female (25YF), a 61-year-old female (61YF), and a 65-year-old female (65YF). The livers from the 25YF, 28YM, and 61YF were used for real-time RT-PCR to determine the expression levels of cell cycle-related genes and TGFBR/ACVR genes, and those from the 49YM, 50YM, and 65YF were used for immunostaining of proteins. Liver tissues were resected from 13-week-old male Fischer 344 rats (Charles River, Yokohama, Japan) and were used for real-time RT-PCR to determine the expression levels and immunohistochemistry.

h-Hepatocytes were isolated from the 12YM as reported previously. ${ }^{7,21}$ Cryopreserved h-hepatocytes from two males, a 9-month-old male (9MM) and a 13-year-old male (13YM), were obtained from In Vitro Technologies (Baltimore, MD); h-hepatocytes from a 10-year-old female (10YF) were purchased from BD Biosciences (San Jose, CA). The hepatocytes from these four donors were used for transplantation experiments into UPA/SCID mice. r-Hepatocytes were isolated from the livers of Fischer 344 rats by collagenase perfusion, ${ }^{22}$ centrifuged through $45 \%$ Percoll at $50 \times g$ for 24 minutes and used for transplantation experiments. These hepatocyte preparations all showed $>80 \%$ of viability, which was determined by the dye extrusion test, and $>99 \%$ of purity, which was determined by microscopic observation.

\section{Transplantation of Hepatocytes}

h- and r-Hepatocytes, $7.5 \times 10^{5}$ and $5 \times 10^{5}$ cells, respectively, were transplanted into the liver of homozygous UPA/ SCID mice, which had been generated by crossing UPA-Tg mice with SCID mice. ${ }^{7}$ Donor h-hepatocytes showed reproducibly high engraftment efficiency similar to fresh $r$-hepatocytes and $\mathrm{RI}>80 \%$ under the optimized conditions. The labeling index (LI) of 5-bromo-2'-deoxyuridine (BrdU) of the transplanted hepatocytes was determined as a measure of DNA synthesis by exposing the host animals to BrdU for 1 hour before sacrifice. ${ }^{23}$

\section{Histochemistry}

Paraffin and frozen sections of $5-\mu \mathrm{m}$ thickness were prepared from liver tissues as detailed previously. ${ }^{7,23}$ The sections were stained with H\&E or subjected to immunohistochemical analysis using the primary antibodies listed in Table 1 together with necessary information. For bright-field immunohistochemistry, the antibodies were visualized with the VECTASTAIN ABC kit (Vector Laboratories, Burlingame, CA) using 3,3'-diaminobenzidine as the substrate. The sections were counterstained with Mayer's hematoxylin. Fluorescent immunohistochemistry was performed using Alexa 488- or 594-conjugated donkey anti-mouse IgG or donkey anti-rabbit IgG (Invitrogen) as secondary antibodies and then with Hoechst 33258 for nuclear staining. Human cytokeratin 8/18 (hCK8/18) antibodies reacted with h-hepatocytes but not with $\mathrm{m}$-hepatocytes. Rat major histocompatability complex class I RT1A (rRT1A) antibodies reacted with $r$-hepatocytes but not with $\mathrm{m}$-hepatocytes. The Rls of $\mathrm{h}$ - and r-hepatocytes $\left(\left.R\right|_{h-h e p}\right.$ and $\mathrm{RI}_{\mathrm{r} \text {-hep }}$, respectively) were calculated as the ratios of the 
Table 1. Antibodies for Immunohistochemical Analysis

\begin{tabular}{|c|c|c|c|c|c|c|}
\hline Antibodies & $\begin{array}{c}\text { Clone } \\
\text { (clone name) }\end{array}$ & Host & Dilution & Fixation & Sections & Supplier \\
\hline Human CK8/18* & $\begin{array}{l}\text { Monoclonal } \\
\text { (NCL 5D3) }\end{array}$ & Mouse & 50 & Aceton & Frozen & MP Biomedicals (Aurora, OH) \\
\hline $\begin{array}{l}\text { Human albumin* } \\
\text { (cross-adsorbed) }\end{array}$ & Polyclonal & Goat & 200 & Formalin & Paraffin & $\begin{array}{l}\text { Bethyl Laboratories } \\
\text { (Montgomery, TX) }\end{array}$ \\
\hline BrdU & $\begin{array}{l}\text { Monoclonal } \\
\text { (Bu20a) }\end{array}$ & Mouse & 50 & Formalin & Paraffin & DAKO (Glostrup, Denmark) \\
\hline Rat RT1A ${ }^{\dagger}$ & $\begin{array}{l}\text { Monoclonal } \\
(\mathrm{OX}-18)\end{array}$ & Mouse & 100 & Aceton & Frozen & $\begin{array}{l}\text { Chemicon International } \\
\text { (Temecula, CA) }\end{array}$ \\
\hline Mouse type IV collagen & Polyclonal & Rabbit & 500 & Aceton & Frozen & LSL (Tokyo, Japan) \\
\hline Human MRP2 ${ }^{\ddagger}$ & Polyclonal & Rabbit & 200 & Aceton & Frozen & Sigma (St. Louis, MO) \\
\hline Human TGFBR2 $2^{\S}$ & Polyclonal & Rabbit & 500 & Aceton & Frozen & Upstate (Billerica, MA) \\
\hline TGF- $\beta 1^{\pi}$ & Polyclonal & Rabbit & 10 & Formalin & Frozen & BioVision (Mountain View, CA) \\
\hline Human desmin§ & Monoclonal & Mouse & 50 & Formalin & Frozen & DAKO \\
\hline Human Smad2 ${ }^{\S}$ & Polyclonal & Rabbit & 50 & Non-fixed & Frozen & $\begin{array}{l}\text { Zymed Laboratories (South San } \\
\text { Francisco, CA) }\end{array}$ \\
\hline $\begin{array}{l}\text { Human Smad3 } \\
\text { Human E-cadherin }\end{array}$ & $\begin{array}{l}\text { Polyclonal } \\
\text { Polyclonal }\end{array}$ & $\begin{array}{l}\text { Rabbit } \\
\text { Rabbit }\end{array}$ & $\begin{array}{l}200 \\
200\end{array}$ & $\begin{array}{l}\text { Formalin } \\
\text { Formalin }\end{array}$ & $\begin{array}{l}\text { Paraffin } \\
\text { Frozen }\end{array}$ & $\begin{array}{l}\text { Zymed Laboratories } \\
\text { Abcam (Cambridge, MA) }\end{array}$ \\
\hline
\end{tabular}

*Human-specific antibody.

${ }^{\dagger}$ Rat-specific antibody.

₹Cross-reactive with rat antigen.

§Cross-reactive with rat and mouse antigens.

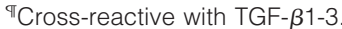

area occupied by $\mathrm{hCK} 8 / 18^{+} \mathrm{h}$-hepatocytes and the area occupied by $\mathrm{rRT} \mathrm{A}^{+}$r-hepatocytes to the entire area examined on immunohistochemical sections from six lobes, respectively, as described previously. ${ }^{7}$ BrdU LIs of $\mathrm{h}$ - and r-hepatocytes ( $\mathrm{LI}_{\mathrm{h} \text {-hep }}$ and $\mathrm{LI}_{\mathrm{r} \text {-hep }}$, respectively) were calculated as the ratios of $\mathrm{BrdU}^{+}$nuclei to hAlb $^{+}$h-hepatocytes and $\mathrm{rRT}_{\mathrm{A}} \mathrm{A}^{+} \mathrm{r}$-hepatocytes, respectively, in 10 randomly selected fields from three different lobes.

A transferase-mediated dUTP nick end-labeling (TUNEL) assay was performed as follows. Paraffin-embedded liver tissues were sectioned, deparaffinized, and subjected to TUNEL analysis using an ApopTag Peroxidase In Situ Apoptosis Detection Kit (Chemicon International, Temecula, CA) following the manufacturer's instructions.

\section{Real-Time RT-PCR}

Total RNA was isolated from normal and chimeric liver tissues using Isogen (Nippon Gene, Tokyo, Japan) and aliquots, $1 \mu \mathrm{g}$ each, were reverse-transcribed with random hexamers using PowerScript Reverse Transcriptase (Clontech, Kyoto, Japan). The expressions of the following genes were measured by real-time RT-PCR using an SYBR Green PCR Master Mix (Applied Biosystems, Foster City, CA) in an ABI Prism 7700 sequence detector (Applied Biosystems): h-forkhead box M1 (hFoxM1), hcyclin dependent kinases (hCdk) 1, hCyclin B1, hCyclin D1, h-cell division cycle 25A (hCdc25A), hTGFBR1, hTGFBR2, hACVR2A, h-glyceraldehyde 3-phosphate dehydrogenase (hGAPDH), rat TGFBR1 (rTGFBR1), rTGFBR2, rACVR2A, and rGAPDH. The gene-specific primers we used are shown in Table 2. These primers correctly amplified the corresponding human/rat genes but not the mouse genes. The relative mRNA expressions of transplanted $\mathrm{h}$ - and $\mathrm{r}$-hepatocytes were quantified using the comparative threshold cycle $\left(\Delta \Delta \mathrm{C}_{\mathrm{T}}\right)$ method $^{24}$ according to the manual provided by Applied Biosystems. hGAPDH and $\mathrm{rGAPDH}$, respectively, were used as the internal reference genes to normalize the expression of human/

Table 2. Primer Sets for Real-Time RT-PCR

\begin{tabular}{|c|c|c|}
\hline Gene & Forward primer & Reverse primer \\
\hline hFoxM1 & 5'-GCATCTACTGCCTCCCTGTG-3' & $5^{\prime}-$ GAGGAGTCTGCTGGGAACG-3' \\
\hline hCdk1 & 5'-AAACTACAGGTCAAGTGG-3' & 5'-GGGATAGAATCCAAGTATTTCTTCAG-3' \\
\hline hCyclin B1 & $5^{\prime}$-CCTGATGGAACTAACTATGTTG-3' & $5^{\prime}$-CATGTGCTTTGTAAGTCCTTGA-3' \\
\hline hCyclin D1 & 5' -TGTGAAGTTCATTTCCAATCCG-3' & $5^{\prime}$-CTGGAGAGGAAGCGTGTGAG-3' \\
\hline hCdc25A & $5^{\prime}$ - CAAAGAGGAGGAAGAGCATGTC-3' & 5'-CCAGGGATAAAGACTGATGAAGAG-3' \\
\hline hTGFBR1 & $5^{\prime}$-GGAATTCATGAAGATTACCAAC-3' & $5^{\prime}$-AGAGTTCAGGCAAAGCTGTAGA-3' \\
\hline hTGFBR2 & 5'-CATGTGTTCCTGTAGCTCTGAT-3' & $5^{\prime}-$ TGCCGGTTTCCCAGGTTGA-3' \\
\hline hACVR2A & 5' -AAGAAGACCCTTTGTTGAAAAATG-3' & 5'-GCAAGGTTTCTCTTAGTCTCATGTC-3' \\
\hline hSmad2 & $5^{\prime}$-AAAGCTTCACCAATCAAGTCC-3' & $5^{\prime}$-СтTCTCTTCСтCTTTAATGGG-3' \\
\hline hSmad3 & 5'-TGGAACTCTACTCAACCCAT-3' & $5^{\prime}$-GGTAAATGTGTTTGGCAGAC-3' \\
\hline$h G A P D H$ & 5'-ACCAGGGCTGCTTTTAACTC-3' & $5^{\prime}$-ATTGATGACAAGCTTCCCG-3' \\
\hline rTGFBR1 & 5'-САСТTCTGATTCCСАСТСТTG-3' & 5'-ATGAAGGAGCAGGAGCTGTA- $3^{\prime}$ \\
\hline rTGFBR2 & $5^{\prime}$-CAAGTCGGTTAACAGCGAT-3' & $5^{\prime}$-GGCTTCTCACAGATGGAGG-3' \\
\hline rACVR2A & 5'-AGCATGGATTGGGAGACTTC- $3^{\prime}$ & 5'-GCCACATTCTTCGTGTAAGTT-3' \\
\hline rGAPDH & 5'-CCAGGGCTGCCTTCTCTTGTGA-3' & 5'-GCCGTTGAACTTGCCGTGGGTA-3' \\
\hline
\end{tabular}

h, human-specific; r, rat-specific. 
rat target genes; $\mathrm{h} / \mathrm{r}$-specific primers were used because there is a difference in the amounts of $h / r-c D N A s$ in the mixed baths from the $\mathrm{h}$ - or $\mathrm{r}$-hep-mouse liver. Before performing quantification with the $\Delta \Delta \mathrm{C}_{\mathrm{T}}$ method, we confirmed that the amplification efficiencies of target and reference primers were approximately equal. The expression levels of the target genes show the relative differences from the normal $\mathrm{h} / \mathrm{r}$-liver controls. For all data, the $\mathrm{h} / \mathrm{r}$ target $\mathrm{C}_{\mathrm{T}}$ value was normalized using the formula: $\Delta \mathrm{C}_{\mathrm{T}}=\mathrm{C}_{\mathrm{T}} \mathrm{h} / \mathrm{r}$ target $-\mathrm{C}_{\mathrm{T}}$ $\mathrm{h} / \mathrm{rGAPDH}$. To determine the relative expression levels, the formula, $\Delta \Delta \mathrm{C}_{\mathrm{T}}=\Delta \mathrm{C}_{\mathrm{T}}$ sample (chimeric livers) $-\Delta \mathrm{C}_{\mathrm{T}}$ calibrator (h/r-livers), was used and $2^{-\Delta \Delta C_{T}}$ was plotted.

\section{Statistics}

Results are shown as the mean \pm SD. Significant differences between groups were detected with Dunnett's multiple comparison test or Student's t-tests using StatView software (SAS Institute Japan, Tokyo, Japan).

\section{Results}

\section{Growth Kinetics for $r$ - and h-Hepatocytes in uPA/SCID Mice}

Twelve mice were transplanted with r-hepatocytes and sacrificed at 1, 2, 3, and 4 weeks after transplantation. Liver sections were subjected to double immunostaining for BrdU and $r_{R T 1 A}$ to determine the $\mathrm{LI}_{r \text {-hep }}$ and the $\mathrm{RI}_{\mathrm{r} \text {-hep }}$ (Figure $1 \mathrm{~A}$ ), where $\mathrm{LI}_{\mathrm{r} \text {-hep }}$ represents the ratio of the BrdU-positive r-hepatocyte number to the total r-hepatocytes in the $\mathrm{r}$ hepatocyte-repopulated region in the r-hep-mouse liver, and $\mathrm{RI}_{\mathrm{r} \text {-hep }}$ represents the ratio of the repopulated $\mathrm{r}$-hepatocytes to the total $r$ - and $m$-hepatocytes in the $r$-hep-mouse liver. $\mathrm{LI}_{\mathrm{r} \text {-hep }}$ was approximately $15 \%$ at 1 week, when $\mathrm{RI} \mathrm{I}_{\text {-hep }}$ was approximately $7 \%$. $\mathrm{RI}_{\mathrm{r} \text { hep }}$ reached almost $100 \%$ at 3 weeks when $\mathrm{LI}_{\mathrm{r} \text {-hep }}$ had markedly decreased to $1 \%$. Finally, $\mathrm{LI}_{\mathrm{r} \text {-hep }}$ returned to the control level $(0.4 \%)$ at 4 weeks, the level of $\mathrm{LI}$ of SCID mouse liver. From these results, we concluded that $r$-hepatocytes terminated proliferation at approximately 3 weeks.

Mice were transplanted with h-hepatocytes isolated from the 9MM (h-hep after transplantation (Figure $1 \mathrm{~B}$ ). $L \mathrm{I}_{\mathrm{h} \text {-hep }}$ and $\mathrm{RI}_{\mathrm{h} \text {-hep, }}$, the corresponding ratios for h-hep-mouse liver, were approximately $10 \%$ and $<1 \%$ at 1 week, respectively. The $\mathrm{LI}_{\mathrm{h} \text {-hep }}$ at this time period was $64 \%$ of the $\mathrm{LI}_{\mathrm{r} \text {-hep. }}$. The rise of $\mathrm{RI}$ h-hep and the decrease of $L I_{h-h e p}$ thereafter were both greatly slow compared with those of the r-hep-mice. $\mathrm{LI}_{\mathrm{h} \text {-hep }}$ returned to the control level at 11 weeks when $\mathrm{RI}_{\mathrm{h} \text {-hep }}$ was still as low as $58 \pm 46 \%$. Thus, it was concluded that h-hepatocytes repopulate the m-liver quite slowly. We believe that this difference in donor proliferative and repopulating activities is due to species-related differences but not experimental variables that might influence transplantation outcomes, because, first, the engraftment efficiencies were similar between the $\mathrm{h}$ - and the r-hepatocytes, second, the viability (>80\%) and the purity ( $>99 \%$ ) of the hepatocyte preparations were comparable between the two types of hepatocytes, and, third, the similar difference was observed
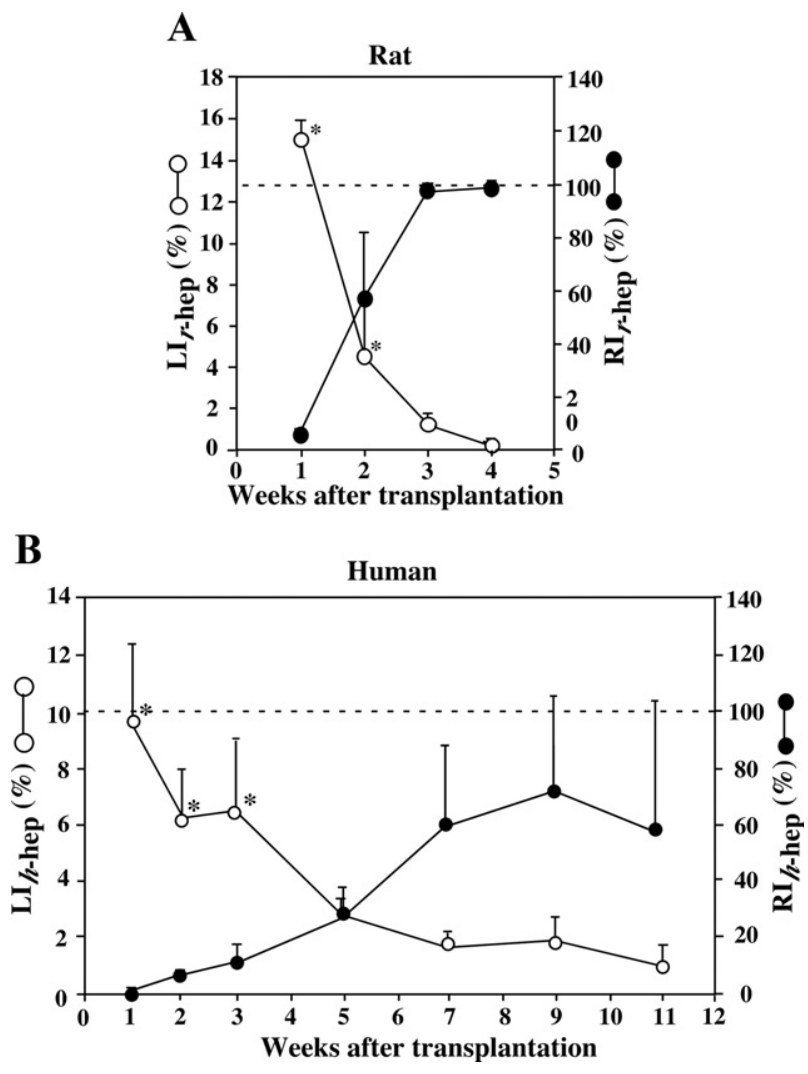

Figure 1. Repopulation of $r$ - and h-hepatocytes in mice. uPA/SCID mice were transplanted with r-hepatocytes (A) and h-hepatocytes (B) and sacrificed at the indicated times (weeks) after transplantation. A: r-hep-Mice. Histological sections were prepared from three different lobes and stained for rRT1A and BrdU. rRT1A ${ }^{+}$and BrdU $^{+}$double-positive hepatocytes and $\mathrm{rRT}^{+} \mathrm{A}^{+}$hepatocytes were counted to determine $\mathrm{LI}_{\mathrm{r}-\mathrm{hep}}$ (open circle) and $\mathrm{RI}_{\mathrm{r}-\mathrm{hep}}$ (closed circle), respectively. B: h-hep $\mathrm{pmM}^{-} \mathrm{Mice} \mathrm{LI}_{\mathrm{h}-\mathrm{hep}}$ (open circle) and $\mathrm{RI}_{\mathrm{h}-\mathrm{hep}}$ (closed circle) were similarly determined, except that h-hepatocytes were identified using hAlb antibodies. The LI of livers taken from control animals (8- to 15 -week-old SCID mice) was $0.4 \pm 0.2 \%(n=3)$. Significant differences compared with normal livers $\left({ }^{*} P<0.05\right)$. The dotted horizontal line indicates RI $=100 \%$.

in the previous report in which h-hepatocytes were also used as donor hepatocytes. ${ }^{9}$

Information regarding proliferative activity of h-hepatocytes was obtained by determining the gene expression levels of five cell cycle promotion genes ( $h C d k 1$, hCyclin $\mathrm{B}, \mathrm{hFoxM1}$ hCdc25A, and hCyclin D) in the h-hep-mouse livers during repopulation, together with those in normal $\mathrm{h}$-livers from three donors. The results are shown as the relative $m R N A$ expression levels against those in the normal h-livers (Figure 2). h-hep-Mouse livers expressed hCdk1 and hCyclin B1 at much and moderately higher levels at 3 to 9 weeks, respectively. The expressions of hFoxM1 and hCdc25A were significantly higher in hhep-mouse livers up to 7 weeks. These genes all reduced the expression to levels comparative to normal $\mathrm{h}$-liver levels at 11 weeks. These results indicate that h-hepatocytes in h-hep-mice terminated growth at 11 weeks after transplantation.

\section{Correlation of $R_{L / B}$ with $R$ in h-Chimeric Mice}

In the experiments shown in Figure 1, we noticed that the h-hep-mouse liver enlarged beyond the normal volume of 


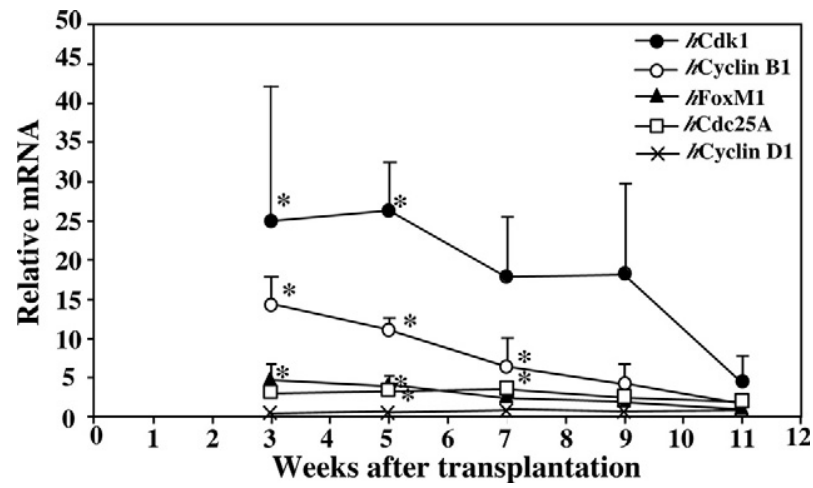

Figure 2. Expressions of cell cycle-related genes during h-hepatocyte repopulation in h-hep-mice. h-hep-Mouse livers were removed at 3 to 11 weeks after transplantation from h-hep-mice shown in Figure $1 \mathrm{~B}$ and subjected to real-time RT-PCR for hCdk1 (closed circle), hCyclin B1 (open circle), hFoxM1 (closed triangle), hCdc25A (open square), and hCyclin D1 $(\times)$. Gene expressions were also determined for normal human livers from the $25 \mathrm{YF}, 28 \mathrm{YM}$, and 61YF donors. Gene expressions were all normalized to hGAPDH expression. The ratio of mRNA expression for each gene in h-hepmouse livers was calculated by dividing the normalized value of each gene of h-hep-mouse livers by the normalized value of corresponding gene of the normal h-livers. The ratios are plotted against weeks after transplantation. The variation of each gene of the normal livers was $1.0 \pm 0.3,1.0 \pm 0.6,1.0 \pm 0.4$ $1.0 \pm 0.5$, and $1.0 \pm 0.3$ for hFoxM1, hCdk1, hCyclin B1, hCyclin D1, and hCdc25A, respectively. Significant differences against normal h-livers $\left({ }^{*} P<0.05\right)$.

the host liver as $\mathrm{Rl}_{\mathrm{h} \text { hep }}$ increased. We assessed a correlation between $\mathrm{RI}_{\mathrm{h} \text {-hep }}$ and liver mass during h-hepatocyte repopulation. A total of $38 \mathrm{~h}$-hep-mice were generated using h-hepatocytes from three donors (9MM, 12YM, and 13YM) and were sacrificed at 11 to 14 weeks after transplantation. No significant increase in blood hAlb levels was observed at 9 to 10 weeks, indicating that the livers then had entered the termination phase of growth, which is consistent with the results shown in Figure 2. Host liver and body weights were measured at sacrifice to calculate $R_{\mathrm{L} / \mathrm{B}}$. Liver sections were prepared from each mouse and stained for hCK8/18 to determine RI. $R_{L / B}$ was then plotted against $\mathrm{Rl}$ (Figure $3 \mathrm{~A}$ ). $\mathrm{R}_{\mathrm{L} / \mathrm{B}}$ increased as $\mathrm{Rl}$ increased, with a correlation coefficient $\left(r^{2}\right)$ of 0.59 . The gross appearances of the selected $h-$ hep-mouse livers are shown in Figure 3, B-D. Livers of an h-hep-mouse with $\mathrm{Rl}=0 \%$ showed $\mathrm{R}_{\mathrm{L} / \mathrm{B}}=6.9 \pm 1.0 \%$ (Figure 3, A and B). Twenty of the 38 h-hep-mice showed $\mathrm{RI}>50 \%$. Five h-hep-mice showed Rls $>80 \%$, one of which had $R_{L / B}=11.8 \%$ and is shown in Figure $3 \mathrm{C}$. The highest $\mathrm{RI}$ was $92.1 \%$, which was obtained in a chimeric h-hep ${ }_{9 M m}$ mouse with $\mathrm{R}_{\mathrm{L} / \mathrm{B}}=19.3 \%$ (Figure 3D). The $\mathrm{R}_{\mathrm{L} / \mathrm{B}}$ for the five mice with RIs $>80 \%$ was $13.2 \pm 3.5 \%$, which was $>2$-fold of the value at the time of transplantation $(6.0 \pm 1.1 \%, n=4)$ or that $(5.4 \pm 0.5 \%, n=3)$ observed in SCID mice (Figure 3A). Importantly, the $\mathrm{R}_{\mathrm{L} / \mathrm{B}}$ of $\mathrm{r}$-hepmice did not change during repopulation (Figure 3E, 5 weeks) and was similar to that of SCID mice (5.4 $\pm 0.5 \%$, $n=3): \mathrm{R}_{\mathrm{L} / \mathrm{B}}=6.5 \pm 1.1,6.3 \pm 0.2,6.4 \pm 0.2$, and $5.8 \pm$ $0.2 \%$ (each $n=3$ ), at 2, 3, 4, and 5 weeks after transplantation, when RIs were 57.1 $\pm 24.7,97.1 \pm 3.0,98.6 \pm$ 2.4 , and $100 \pm 0.0 \%$, respectively. This fact suggests that the increase in r-hepatocyte number and the death of injured m-hepatocytes are normally balanced in the $r$ hep-mouse liver. However, $\mathrm{R}_{\mathrm{L} / \mathrm{B}}$ of $\mathrm{h}$-hep-mice increased as the $\mathrm{Rl}$ increased as above, suggesting a possible
A

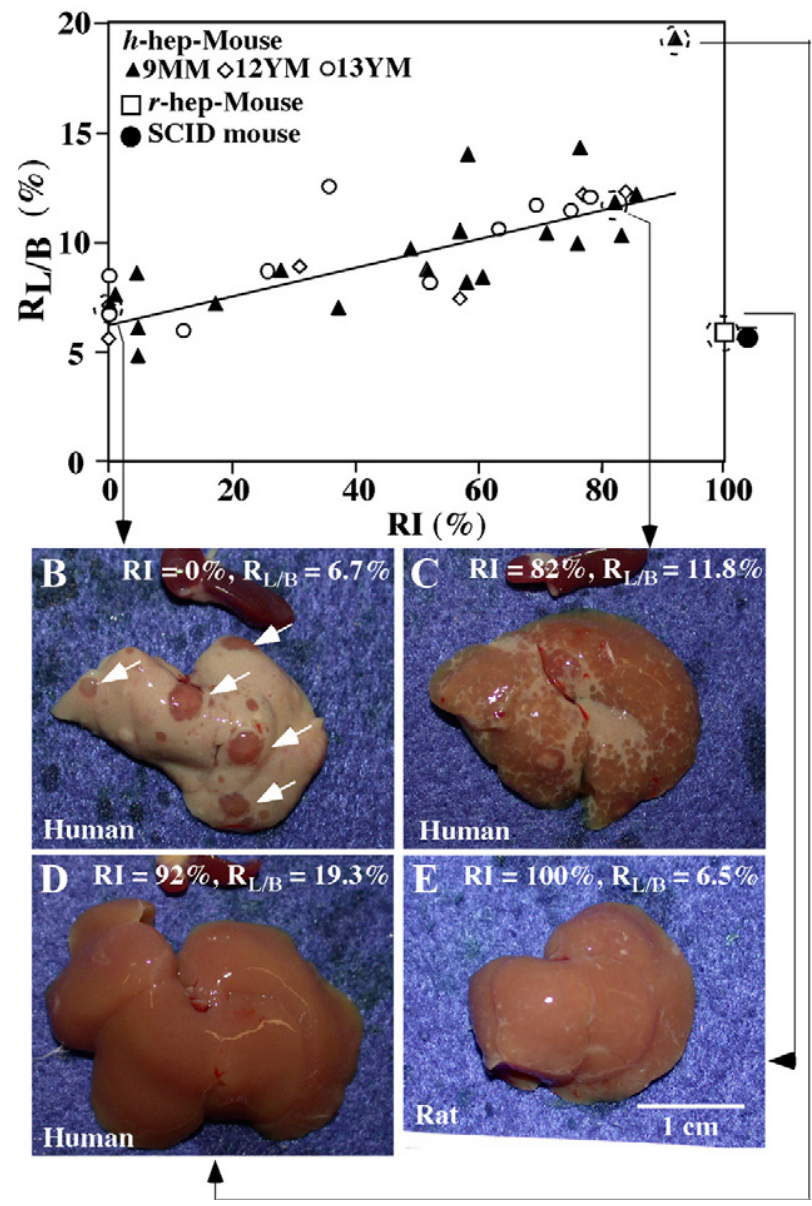

Figure 3. Correlation of $\mathrm{R}_{\mathrm{L} / \mathrm{B}}$ with $\mathrm{RI}$ in h-hep-mice. A: Twenty-one, 6 , and $11 \mathrm{~h}$-hep-mice were produced by transplanting hepatocytes from the $9 \mathrm{MM}$, $12 \mathrm{YM}$, and $13 \mathrm{YM}$ donors, respectively, and then sacrificed at 11 to 14 weeks after transplantation. $\mathrm{R}_{\mathrm{L} / \mathrm{B}}$ and RI were determined at sacrifice and plotted together. Closed triangle, 9MM hepatocytes; open diamond, 12YM hepatocytes; open circle, 13YM hepatocytes. Four r-hep-mice were produced and sacrificed at five weeks after transplantation when the repopulation had completed, and $\mathrm{R}_{\mathrm{L} / \mathrm{B}}$ and RI were determined (open square). $\mathrm{R}_{\mathrm{L} / \mathrm{B}}$ was also determined for three 8- to 15-week-old SCID mice (closed circle). B-D: Gross appearances of h-hepmouse livers at 11 weeks. The four long arrows in the figure starting from each of mouse symbols in $\mathbf{A}$ point to the photos of the corresponding mouse livers shown in $\mathbf{B}, \mathbf{C}, \mathbf{D}$, and $\mathbf{E}$, respectively. B: The liver of an h-hep pmm $_{9}$ mouse with $\mathrm{RI}=0 \%$ and $\mathrm{R}_{\mathrm{L} / \mathrm{B}}=6.7 \%$. Arrows indicate reddish colonies of $\mathrm{m}$-hepatocytes that deleted the transgene. Whitish regions are occupied by Tg host hepatocytes. The dark red-colored organ placed above the liver is spleen removed from the same recipient. C: The liver of an h-hep9Mм mouse with $\mathrm{RI}=82 \%$ and $\mathrm{R}_{\mathrm{L} / \mathrm{B}}=$ $11.8 \%$. D: The liver of an h-hep $p_{9 M}$ mouse with $\mathrm{RI}=92 \%$ and $\mathrm{R}_{\mathrm{L} / \mathrm{B}}=19.3 \%$. E: The liver of an $\mathrm{r}$-hep-mouse with RI $=100 \%$ and $\mathrm{R}_{\mathrm{L} / \mathrm{B}}=6.5 \%$. Scale bar $=1 \mathrm{~cm}$.

imbalance between $\mathrm{h}$-hepatocyte proliferation and $\mathrm{m}$ hepatocyte death.

To test this possibility we performed the TUNEL analysis and determined the ratios (\%) of the TUNEL ${ }^{+}$(dead) m-hepatocytes during the repopulation of h-hepatocytes as follows: $0.5 \pm 0.1,0.6 \pm 0.2,1.2 \pm 0.1,0.6 \pm 0.3$ $0.2 \pm 0.1,3.9 \pm 4.7$, and $8.5 \pm 6.8$ at $1,2,3,5,7,9$, and 11 weeks (each $n=3$ ), respectively. The ratios were quite low until 7 weeks after transplantation and were much lower than those of the $\mathrm{BrdU}^{+} \mathrm{h}$-hepatocytes shown in Figure 1B ( $\sim 10 \%$ at 1 week and $\sim 2 \%$ at 7 weeks). Similar TUNEL analysis showed a TUNEL ${ }^{+}$ratio of $18.8 \pm 6.1 \%(n=3)$ for r-hep-mice at 3 weeks after transplantation, which is con- 
siderably higher than that of h-hep-mice at 3 weeks (1.2 \pm $0.1 \%)$. Based on these analyses, we concluded that the proliferation rate of h-hepatocytes is higher than the death rate of $\mathrm{m}$-hepatocytes, which resulted in the enlargement of liver in h-hep-mice.

\section{Histological Architecture of Sinusoids and Bile Canaliculi in Chimeric Mouse}

Liver sinusoids were histologically examined, because their structures reflect the proliferation status of hepatocytes: their structures are compressed ${ }^{25}$ and become vague $^{26}$ during vigorous hepatocyte proliferation. r-hepand h-hep ${ }_{9 м}$ Mice were generated and sacrificed in the proliferation (at 2 and 5 weeks after transplantation for r-hep- and h-hep 9 m mice, respectively) and proliferation termination phases (at 5 and 14 weeks for r-hep- and h-hep (Figure 4). Normal livers from Fischer 344 rats and the $65 Y F$ donor were used as normal $r$ - and h-liver controls, respectively. H\&E sections clearly showed the single-cell structures of hepatic plates in normal r-livers (Figure 4A)

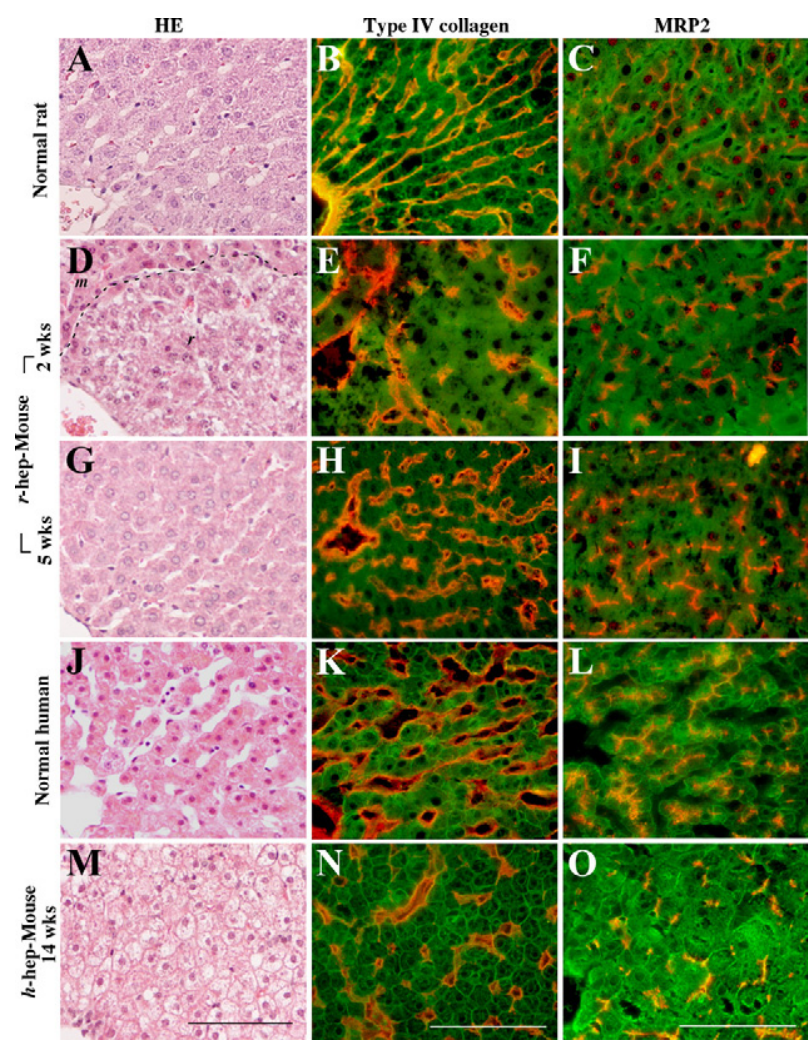

Figure 4. Histological characteristics of $r$-hep- and h-hep-mouse livers Normal $\mathrm{r}$ - and h-livers were obtained from 13-week-old male Fischer 344 rats (A-C) and from a 65 YF donor $(\mathbf{J}-\mathbf{L})$, respectively. r-hep-Mice and h-hep-mice were produced as shown in Figure 1. The former were sacrificed at two (proliferation phase, D-F) and five weeks (wks) after transplantation (termination phase, $\mathbf{G}-\mathbf{I}$ ) and the latter at 14 weeks (termination phase, $\mathbf{M - O}$ ). Liver sections were stained with $\operatorname{H\& E}(\mathbf{A}, \mathbf{D}, \mathbf{G}, \mathbf{J}$, and $\mathbf{M})$ and for type IV collagen (red, $\mathbf{B}, \mathbf{E}, \mathbf{H}, \mathbf{K}$, and $\mathbf{N}$ ) and MRP2 (red, $\mathbf{C}, \mathbf{F}, \mathbf{I}, \mathbf{L}$, and $\mathbf{O}$ ). The sections from rats and r-hep-mice were additionally stained for rRT1A (green, B, C, E, F, H, and $\mathbf{I}$ ) and those from the human and h-hep-mice for hCK8/18 (green, $\mathbf{K}, \mathbf{L}$, $\mathbf{N}$, and $\mathbf{O}$ ) to identify transplanted $\mathrm{r}$ - and h-hepatocytes, respectively. The dashed line in $\mathbf{D}$ shows the boundary between r-hepatocyte $(r)$ and $\mathrm{m}$ hepatocyte regions $(m)$. Scale bar $=100 \mu \mathrm{m}$. and h-livers (Figure 4J). Sections were stained for type IV collagen, an indicator of the subsinusoidal space, ${ }^{26}$ and multidrug resistance-associated protein 2 (MRP2), a maker of the canalicular organic anion transporters. ${ }^{27}$ These proteins were localized as expected in normal r-livers (Figure 4, $\mathrm{B}$ and $\mathrm{C}$ ) and h-livers (Figure $4, \mathrm{~K}$ and $\mathrm{L}$ ).

H\&E-stained sections from r-hep- and h-hep-mouse livers at 5 and 14 weeks, respectively, showed complete repopulation (Figure 4, G and M, respectively), but their histological features were quite different. h-Hepatocytes were less eosinophilic than r-hepatocytes, as reported previously, ${ }^{7}$ and swollen and contained less cytoplasm, with wisps of accumulated glycogen, as described previously. ${ }^{8}$ Single-cell plates were rarely observable in the

A

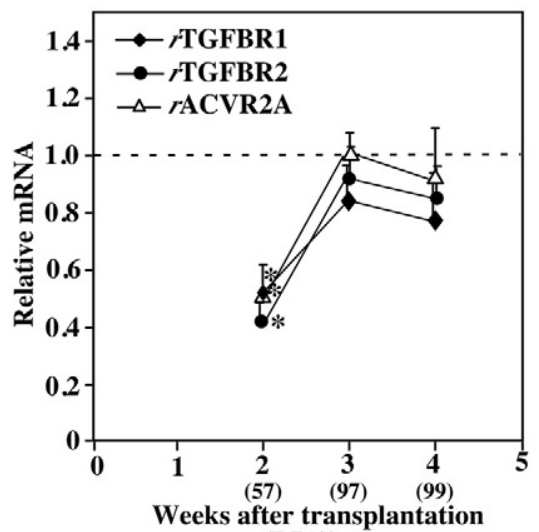

(RI\%)

B

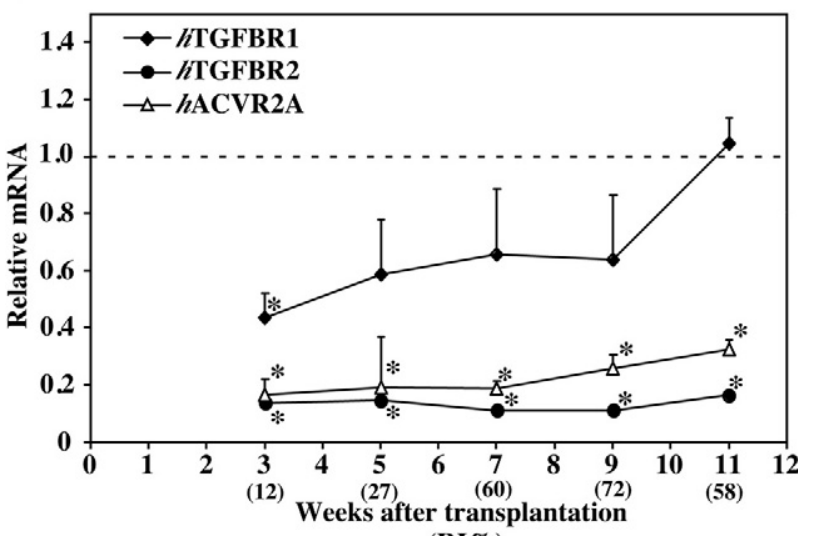

(RI\%)

Figure 5. Gene expressions of TGFBR1, TGFBR2, and ACVR2A in r-hepand h-hep-mouse livers. Real-time RT-PCR was performed by using total mRNA isolated from the livers of r-hep- and h-hep 9 m mice shown in Figure 1 as templates, and each result was normalized to that of rGAPDH and hGAPDH. Likewise real-time RT-PCR was performed for liver tissues from 13-week-old male rats and those from the 25YF, 28YM, and 61YF human donors as the normal rat and human controls, respectively. mRNA abundance in $\mathrm{r}$ - and h-chimeric mice was divided by that of the normal $\mathrm{r}$ - and h-livers, respectively, and is shown as relative mRNA abundance (ordinary axis) in $\mathbf{A}$ for r-hep-mice and in $\mathbf{B}$ for h-hep-mice. Normal livers in $\mathbf{A}$ were obtained from three 13-week-old male rats and those in $\mathbf{B}$ from three donors, 25YF, 28YM, and $61 Y F$. The dotted horizontal lines show the average expression level in normal livers (1.0). The variations of the normalized rTGFBR1, rTGFBR2, rACVR2, hTGFBR1, hTGFBR2, and hACVR2 were $1.0 \pm 0.2,1.0 \pm 0.2,1.0 \pm 0.2,1.0 \pm$ $0.2,1.0 \pm 0.4$, and $1.0 \pm 0.2$, respectively. Values represent the mean $\pm \mathrm{SD}(n=$ 3). Significant differences compared with normal livers ( $P<0.05)$. "RI $\%$ " shows the average RI calculated from three mice. Closed diamond, TGFBR1; closed circle, TGFBR2; and open triangle, ACVR2A. 
h-hepatocyte-regions in h-hep-mice at 14 weeks (Figure $4 \mathrm{M}$ ), and sinusoids were obscure. Type IV collagen immunostains demonstrated multicell-layer-thick hepatic plates (Figure 4N). The MRP2 protein was randomly distributed in the intercellular space (Figure 40). Similar histological structures were observed in the h-hepatocyte regions at 5 weeks (data not shown). Likewise sinusoidal structures were not distributed in an orderly fashion in the r-hepatocyte regions of r-hep-mice at 2 weeks when $r$ hepatocytes were in the proliferation phase (Figure 4, D-F), losing vessel continuity along the portal-central axis. However, r-hep-mice at 5 weeks after transplantation regained the normal arrangement of hepatic plates and sinusoids (Figure 4G), which was consistent with the distributions of type IV collagen and MRP2 (Figure 4, H and I). These proteins were located as in normal r-liver, indicating the reconstruction of the resting liver structure with single hepatic plates along the portal-central axis. These results demonstrate that the h-hepatocytes were incapable of reconstructing the resting liver structure even at 14 weeks after transplantation.

The length of the long axis of hepatocytes was determined on H\&E-stained sections from $r$ - and h-hep-mice shown in Figure 4 as a measure of size, which showed no significant differences among $\mathrm{m}$ (host)-, r-, and h-hepa- tocytes in chimeric livers: uPA-expressing m-hepatocytes in h-heр 9 мм mice at 11 weeks after transplantation, $19.5 \pm$ $4.5 \mu \mathrm{m}(n=3)$; uPA-expressing m-hepatocytes in r-hepmice at 2 weeks, $19.7 \pm 4.3 \mu \mathrm{m}(n=3)$; r-hepatocytes in r-mice at 5 weeks, $22.7 \pm 2.9 \mu \mathrm{m}(n=3)$; and h-hepatocytes in h-hep-mice at 11 to 14 weeks, $22.5 \pm 1.8 \mu \mathrm{m}$ ( $n=$ $6)$. This result clearly indicated that the observed enlargement of the h-hep-mouse liver was caused by hyperplasia but not hypertrophy of h-hepatocytes.

\section{TGF- $\beta$ Signaling in r-hep- and h-hep-Mouse Livers}

TGF- $\beta$ and activin play active roles in the termination of liver regeneration. ${ }^{14,15,18-20,28}$ The mRNA expressions of TGFBR1, TGFBR2, and ACVR2A were determined in rhep-mouse livers at 2, 3, and 4 weeks after transplantation and in h-heр 9 мм mouse livers at 3, 5, 7, 9, and 11 weeks and compared with those of normal $\mathrm{r}$ - and h-liver controls, respectively. In r-hep-mice at 2 weeks (proliferation phase, $\mathrm{RI}_{\mathrm{r} \text {-hep }}=57 \%$ ), rTGFBR1, rTGFBR2, and rACVR2A expressions were suppressed to half those of normal $r$-livers and gradually returned to normal levels at 3 and 4 weeks (termination phase, $\mathrm{RI}_{\mathrm{r} \text {-hep }}=97$ and 99\%,
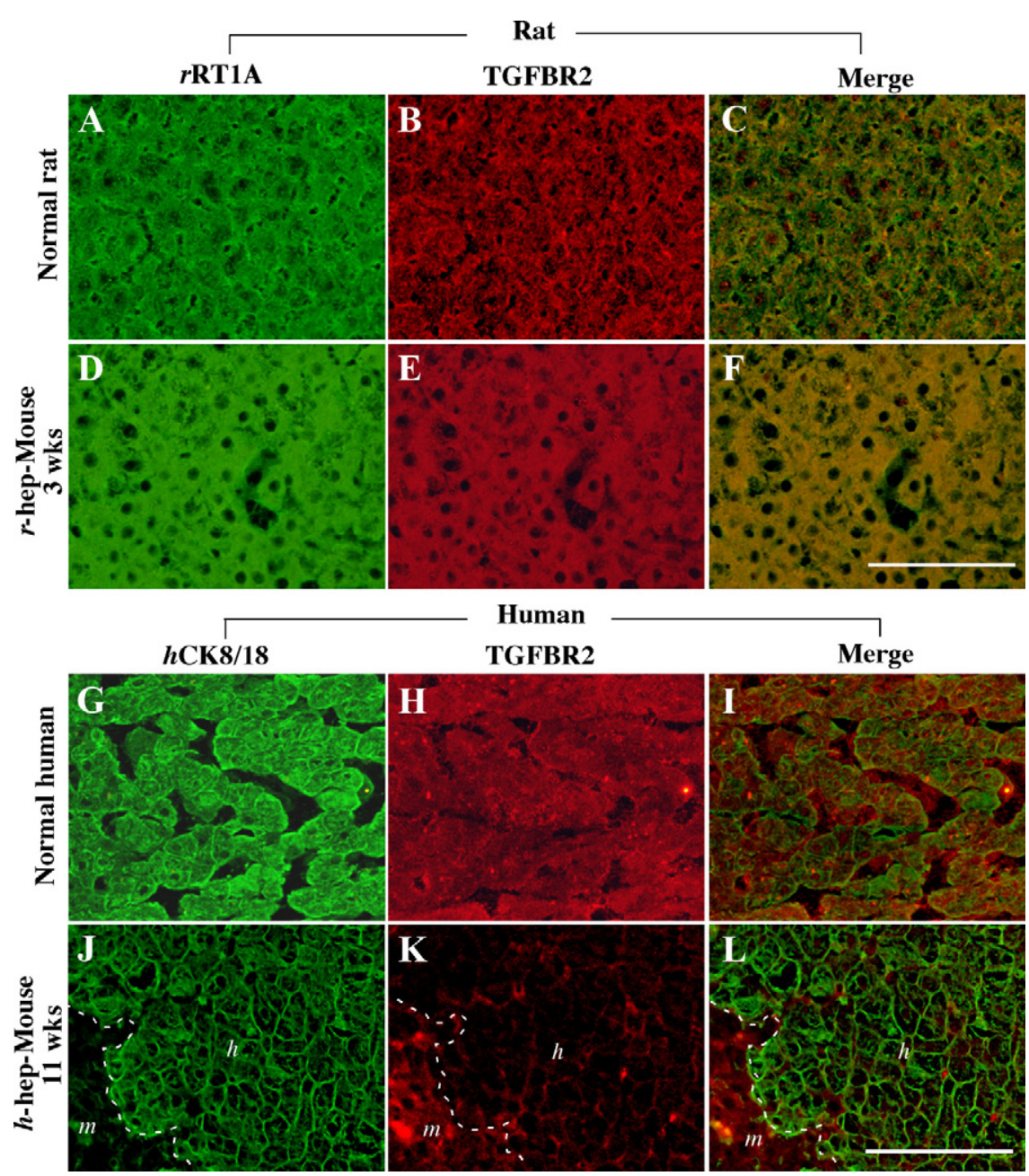

Figure 6. Identification and distribution of TGFBR2 in normal and chimeric livers. uPA SCID mice were transplanted with $r$ - and h-hepatocytes ${ }_{9 \mathrm{MM}}$ and sacrificed at 3 and 11 weeks after transplantation, respectively, when the transplanted hepatocytes had terminated proliferation. Two series of double immunohistochemical examinations were performed on liver tissues, one for rat series (Rat) shown in $\mathbf{A}-\mathbf{F}$ that contained normal r-liver (Normal rat) shown in $\mathbf{A}-\mathbf{C}$ and r-hep-mouse liver (D-F) and the other for the human series (Human) shown in $\mathbf{G}-\mathbf{L}$ that contained 9MM donor liver as control normal h-liver (Normal human, G-I) and h-hep-mouse liver (J-L). Liver sections of rat series were doublestained for rRT1A for identifying r-hepatocytes (green; $\mathbf{A}$ and $\mathbf{D}$ ) and TGFBR2 (red; $\mathbf{B}$ and $\mathbf{E}$ ) and those of human series for hCK $8 / 18$ for identifying h-hepatocytes (green; $\mathbf{G}$ and $\mathbf{J}$ ) and TGFBR2 (red; $\mathbf{H}$ and $\mathbf{K}$ ). Images $\mathbf{A}$ and $\mathbf{B}, \mathbf{D}$ and $\mathbf{E}, \mathbf{G}$ and $\mathbf{H}$, and $\mathbf{J}$ and $\mathbf{K}$ were merged and are shown in $\mathbf{C}, \mathbf{F}, \mathbf{I}$, and $\mathbf{L}$, respectively. Similar staining results were obtained from three different mice of each series. The dashed lines in $\mathbf{J}-\mathbf{L}$ indicate the boundary between h-hepatocyte $(b)$ and $m$-hepatocyte regions $(m)$. Scale bar $=100 \mu \mathrm{m}$. 
respectively) (Figure 5A) as reported in the regeneration of partial hepatectomized r-liver. ${ }^{29}$ In contrast, their expression profiles in h-hep-mouse livers were quite different (Figure 5B). At 3 weeks (proliferation phase, $\mathrm{RI}_{\mathrm{h} \text {-hep }}=$ $12 \%)$, hTGFBR2 and hACVR2A were expressed at levels less than one-third of normal levels; expression remained low throughout the 11-week-long observation period. The suppression of the expression of these genes was reproducible, because similar results were obtained from hhep-mice generated with another donor (10YF): the ratios of expression levels of hTGFBR2 and hACVR2A in the h-hep-mice at 9 to 11 weeks after transplantation to those in the normal human livers were $0.19 \pm 0.05(n=3)$ and $0.19 \pm 0.02(n=3)$, respectively. The expression of hTGFBR1 mRNA was high compared with that of these two mRNAs at 3 weeks and gradually increased until reaching the normal levels at 11 weeks.

The expression of TGF- $\beta$ receptor, TGFBR2, was immunohistochemically examined in $r$ - and $h$-hep 9 mm mouse livers at 3 and 11 weeks when the mice showed $\mathrm{RI}=97 \pm 3 \%(n=3)$ and $58 \pm 46 \%(n=3)$, respectively, together with staining for rRT1A and hCK8/18 to identify $r$ and h-hepatocytes, respectively (Figure 6). As with normal r-hepatocytes (Figure 6, A-C), the rRT1A ${ }^{+}$r-hepatocytes in r-hep-mice were stained heavily for TGFBR2 (Figure 6, D-F). Likewise normal h-hepatocytes abundantly expressed TGFBR2 (Figure 6, G-I). In contrast, TGFBR2 was hardly detectable in hCK8/18 ${ }^{+}$h-hepatocytes in h-hep-mice (Figure 6, J-L). The anti-TGFBR2 antibody used was cross-reactive with $r$ - and $m$-TGFBR2. The TGFBR2 ${ }^{+}$cells in the $m$-hepatocyte region seen in Figure 6K were largely m-hepatocytes according to their morphology. Moderately TGFBR2 ${ }^{+}$cells in the h-hepatocyte region shown in Figure 6K were mostly m-nonparenchymal cells and few h-hepatocytes (Figure 6, K and L). These results indicated that h-hepatocytes in h-hep-mice maintain low sensitivity to TGF- $\beta$, although the expression of TGFBR1 was up-regulated at 11 weeks after transplantation. It is known that TGF- $\beta$ initially binds to TGFBR2, and TGF- $\beta$ signals are transferred through the heterodimers of TGFBR1 and TGFBR2. ${ }^{16}$ TGF- $\beta$-expressing cells were identified in liver sections from $r$ - and h-hepmice during the proliferation and termination phases by double-immunostaining for desmin and TGF- $\beta$ (Figure 7). Compared with the control (Figure 7, A-C; normal liver from wild-type SCID mice), tissues collected from the injured livers of UPA/SCID mice contained abundant desmin $^{+}$HSCs that were all heavily expressing TGF- $\beta$ (Figure 7, D-F) as reported previously. ${ }^{2}$ Very few desmin $^{+}$cells were observed in r-hep-mice at 2 weeks (Figure 7, G-I) or in h-hep-mice at 5 weeks (Figure 7, $\mathrm{M}-\mathrm{O})$, suggesting that very few $\mathrm{m}-\mathrm{HSC}$ invaded the xenogeneic hepatocyte colonies during the proliferation phase. These cells were all TGF- $\beta^{-}$. m-HSCs increased in number in xenogeneic hepatocyte colonies from both $r$ - and h-hep-mice, particularly in the former, at 3 and 11 weeks (termination phase), respectively (Figure 7 , $\mathrm{J}$ and $\mathrm{P}$ ). During the termination phase, $\mathrm{m}-\mathrm{HSCs}$ in $r$-hepatocyte colonies from $r$-hep-mice were TGF- $\beta^{+}$(Figure $7, \mathrm{~J}-\mathrm{L}$ ). However, importantly, m-HSCs in h-hepatocyte colonies of h-hep-mice were TGF- $\beta^{-}$(Figure 7,

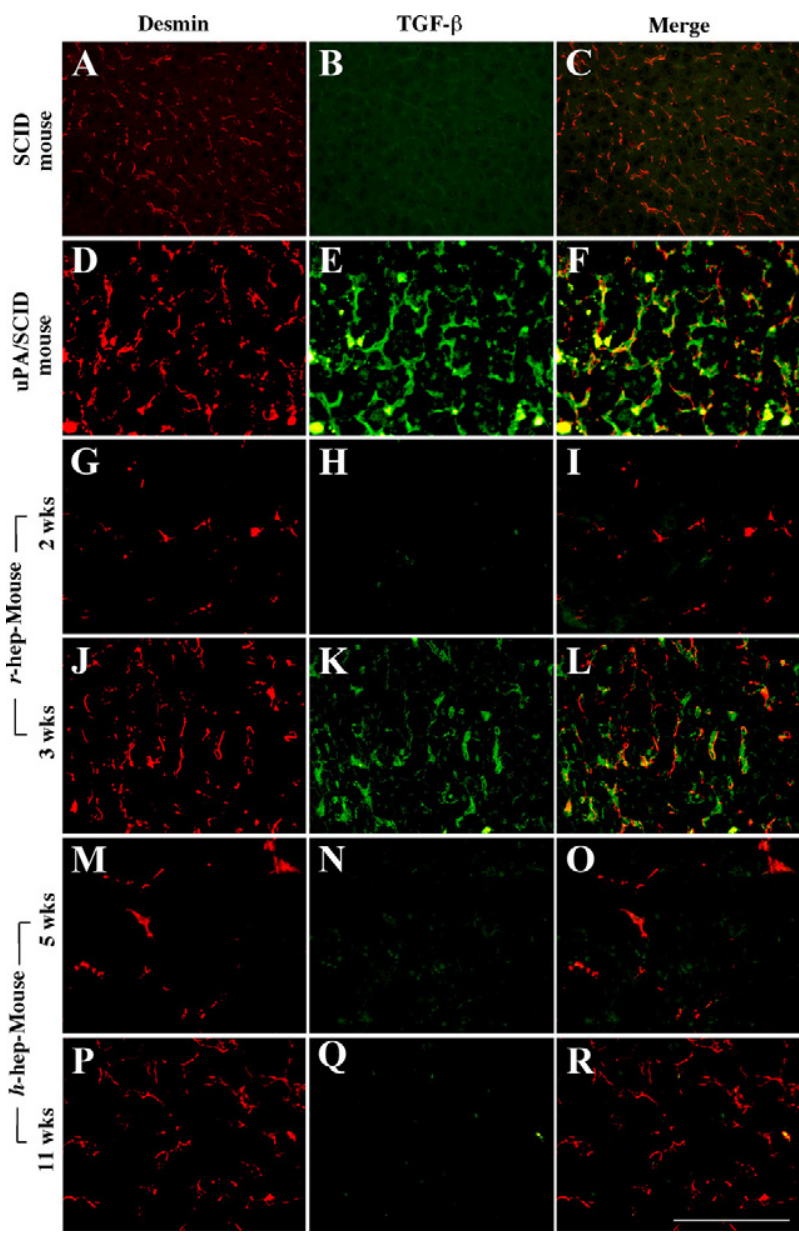

Figure 7. Expression and distribution of TGF- $\beta$ in normal and chimeric mouse livers. Livers were removed, respectively, from 3-month-old wild-type SCID mice (A-C), 1-month-old uPA/SCID mice (D-F, injured region), r-hepmice at $2(\mathbf{G}-\mathbf{I})$ and three $(\mathbf{J}-\mathbf{L})$ weeks after transplantation, and h-hep-mice at $5(\mathbf{M}-\mathbf{O})$ and 11 weeks $(\mathbf{P}-\mathbf{R})$. These livers were cryosectioned and double-immunostained for desmin $(\mathbf{A}, \mathbf{D}, \mathbf{G}, \mathbf{J}, \mathbf{M}$, and $\mathbf{P}$, red) and TGF- $\beta$ (B, $\mathbf{E}, \mathbf{H}, \mathbf{K}, \mathbf{N}$, and $\mathbf{Q}$, green). The two sets of photographs are merged and shown in the corresponding panels $(\mathbf{C}, \mathbf{F}, \mathbf{I}, \mathbf{L}, \mathbf{O}$, and $\mathbf{R})$ in the right column. Serial sections from $\mathrm{r}$ - and h-hep-mouse livers were immunostained for rRT1A and hCK8/18 to identify $\mathrm{r}$ - and h-hepatocytes, respectively (data not shown). Similar results were obtained from three different mice. Scale bar $=100 \mu \mathrm{m}$

P-R). HSCs that express TGF- $\beta$ should be all m-HSCs in the chimeric mice, because the purity of the transplanted r- or h-hepatocytes was $>99 \%$. In r-and h-normal livers, TGF- $\beta^{+}-$HSCs were rarely observed (data not shown).

Smad proteins are major intracellular effectors in both TGFBR and ACVR signaling. The distributions of Smad2/3 were examined on liver sections prepared from $r$ - and $h$ hep-mice at 3 and at 11 weeks (termination phase of $r$ - and h-hep-mice, respectively), respectively, together with liver tissues from Fischer 344 rats and the 49YM donor as normal controls (Figure 8). The nuclei of normal r-livers (Figure 8, A and B) and h-livers (Figure 8, G and H) were both $S$ mad2 ${ }^{-} / 3^{-}$. In contrast, the nuclei of $r$-hepatocytes in $r$-hep-mouse were strongly Smad ${ }^{+} / 3^{+}$(Figure $8, D$ and $E$ ), supporting the evidence that $r$-hepatocytes are activated by TGF- $\beta$ from m-HSCs. However, as expected, h-hepatocytes showed little or no Smad2/3 immunoreactivity (Figure 8, J and K), suggesting that 

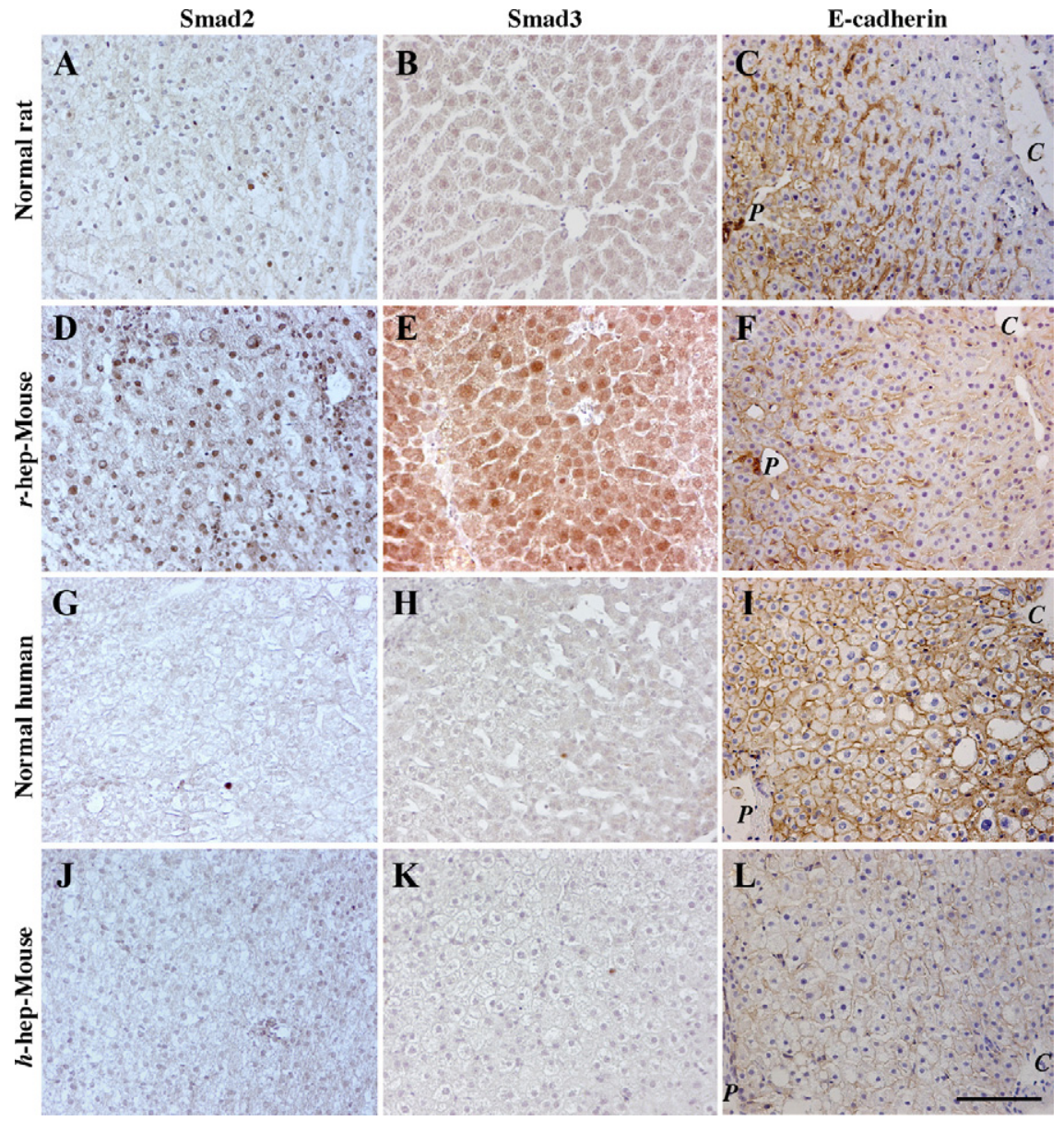

Figure 8. Localization of $\operatorname{Smad} 2 / 3$ and E-cadherin in chimeric mouse liver. Livers were obtained from 13-week-old male Fischer 344 rats (A-C, Normal rat), normal donors (49YM, 50YM, and 65YF) (G-I, Normal human), r-hep-mice at three weeks (D and $\mathbf{E})$ and five weeks $(\mathbf{F})$, and 9MM-h-hep-mice at 11 weeks ( $\mathbf{J}$ and $\mathbf{K}$ ) and 14 weeks (L) after transplantation. They were immunostained for $\operatorname{Smad} 2(\mathbf{A}, \mathbf{D}, \mathbf{G}$, and $\mathbf{J}), \operatorname{Smad} 3$ $(\mathbf{B}, \mathbf{E}, \mathbf{H}$, and $\mathbf{K})$, and E-cadherin $(\mathbf{C}, \mathbf{F}, \mathbf{I}$, and $\mathbf{L})$. Positive signals are brown. Histological examinations were individually performed for these livers in each category, and we obtained similar results. Representative photos are shown here. The photos of Normal human were from 49YM liver. In $\mathbf{C}, \mathbf{F}, \mathbf{I}$, and $\mathbf{L}, P$ and $C$ indicate portal and central veins, respectively. Scale bar $=100 \mu \mathrm{m}$.
TGF- $\beta$ and activin signaling was lacking in h-hep-mice. In h-hep mice from another donor (10YF, 9 to 11 weeks after transplantation), the immunohistological results for TGF- $\beta$, Smad2, and Smad3 showed the same tendencies as the results shown in Figures 7 and 8 (data not shown), suggesting that the deficiency of TGF- $\beta$ signaling is not attributed to the possible immaturity because of the young age (9MM) of the donor.

To obtain an additional evidence for the TGF- $\beta$ signaling deficiency in h-hep-mice, we examined the expression of E-cadherin in the chimeric mouse, which is one of the TGF- $\beta$ target genes. ${ }^{30}$ Normal $r$-livers expressed the E-cadherin protein in the periportal zone restrictedly (Figure $8 \mathrm{C}$ ), and a similar distribution pattern was observed in the r-hep-mouse livers (Figure 8F). In contrast to normal r-livers, normal h-livers uniformly and evenly expressed E-cadherin (Figure 8l). Its expression was significantly low in the hhepatocyte region of the h-hep-mouse liver (Figure 8I) compared with that in the normal h-livers.

\section{Participation of m-HSCs in the Donor Hepatocyte Colonies}

As shown in Figure 7, the xenogeneic hepatocyte regions contained fewer m-HSCs than the injured host regions, especially in the proliferation phase. We further investigated this phenomenon using desmin as a HSC marker.
The desmin ${ }^{+}$cells were scarce in both $r$ - and h-hepatocyte colonies in r-hep-mice at 2 weeks (Figure 9A) and in h-hep-mice at 5 weeks after transplantation (Figure 9B), respectively, compared with the degenerating $\mathrm{m}$-hepatocyte regions that surrounded the corresponding donor cell regions. These xenogeneic hepatocytes were both in the proliferation phase (Figure 1). This paucity of HSCs seemed to be related to the fact that the sinusoids were still under reconstruction (Figure 4E) in r-hep-mouse liver at 2 weeks and in h-hep-mouse liver at 5 weeks (data not shown). HSCs were abundant in r-hepatocyte colonies in r-hep-mice at 3 weeks (termination phase) (Figure 9C), supporting the result of Figure $7 \mathrm{~J}$. The HSCs also increased in density in h-hepatocyte colonies of h-hepmice at 11 weeks (Figure 9D), also supporting the result of Figure 7P. However, the density was apparently lower than that in r-hepatocyte colonies, most probably reflecting the fact that the sinusoids were less developed than in $r$-hepatocyte colonies in the termination phase (Figure $4 \mathrm{~N}$ versus Figure $4 \mathrm{H}$, respectively). These desmin ${ }^{+} \mathrm{HSC}$ s were not derived from h-HSCs, because, first the purity of the transplanted h-hepatocytes was $>99 \%$ and second h-HSCs do not express desmin. ${ }^{31}$ The m-HSC-occupied areas (red-colored areas) were measured in the entire normal mouse (wild-type SCID mouse) liver (control) and in the xenogeneic hepatocyte regions of chimeric livers on immunostained sections. The ratios $\left(R_{\mathrm{HSC}}\right)$ of red-colored areas 

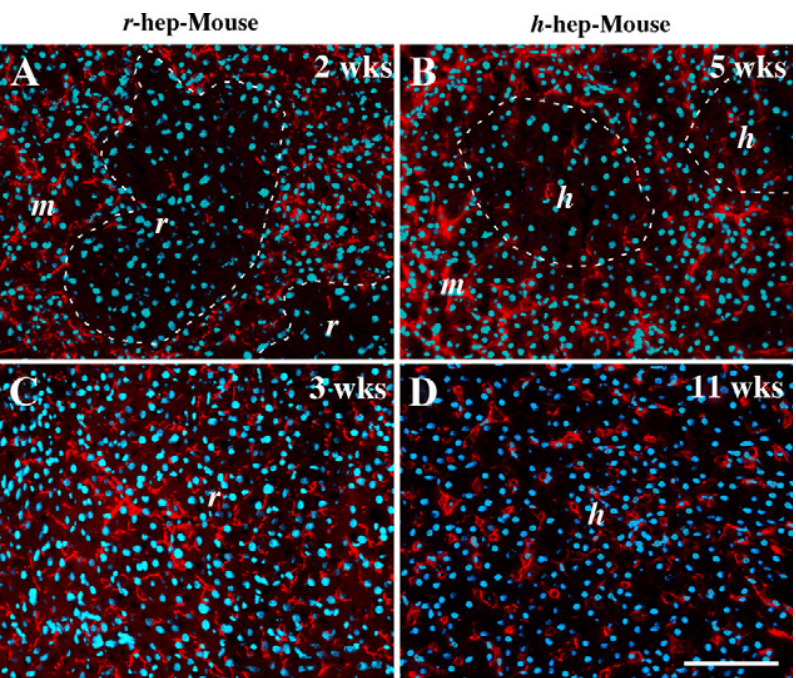

$\mathbf{E}$

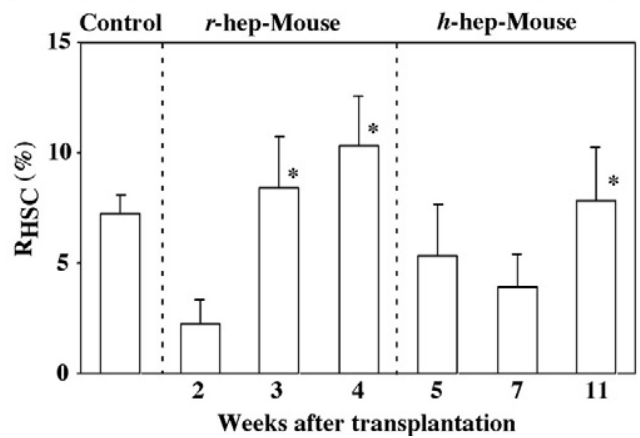

Figure 9. Distribution of $\mathrm{m}$-HSCs in $\mathrm{r}$ - and h-hep-mice. Liver sections from r-hep-mice at two (proliferation phase, $\mathbf{A}$ ) and three (termination phase, $\mathbf{C}$ ) weeks and from 9MM h-hep-mice at five (proliferation phase, B) and 11 (termination phase, $\mathbf{D}$ ) weeks after transplantation were immunostained for desmin (red). The nuclei were stained with Hoechst 33258 (blue). Serial sections from the r-hep- and h-hep-mouse livers were immunostained for rRT1A and hCK8/18 to identify r-and h-hepatocytes, respectively (data no shown), from which the boundary between the host $(m)$ and transplanted ( $r$ or $h$ ) hepatocyte regions was determined, as indicated by the dashed lines in $\mathbf{A}$ and $\mathbf{B}$. Similar results were obtained from three different mice. Scale bar $=100 \mu \mathrm{m}$. E: Changes in the ratio of desmin ${ }^{+}$cells in xenogeneic hepatocyte regions during liver repopulation. Liver sections from 3-month-old wildtype SCID mice (control), r-, and h-hep-mice at the indicated weeks after transplantation were immunostained for desmin. Serial sections were stained with anti-rRT1A and -hCK8/18 antibodies to identify r- and h-hepatocytes, respectively. The ratio $\left(\mathrm{R}_{\mathrm{HSC}}\right)$ of desmin ${ }^{+}$areas over the measured areas was calculated in the xenogeneic hepatocyte region using NIH imaging software and is expressed as a percentage. Data represent the mean $\pm \mathrm{SD}$ of desmin ${ }^{+}$area per section in a total of 15 randomly selected fields $(n=3)$. Asterisks at three and four weeks in the panel for $\mathrm{r}$-hep-mice indicate significant differences versus the value at two weeks. The asterisk at 11 weeks in the panel of h-hep-mice indicates a significant difference versus the value at five weeks.

to either the entire liver of SCID mouse or to the xenogeneic region of chimeric liver were calculated and are shown in Figure $9 \mathrm{E}$. The $\mathrm{R}_{\mathrm{HSC}}$ in normal mice was $7.3 \pm 0.8 \%$. In r-hep-mice, the $R_{\text {HSC }}$ was $2.3 \pm 1.1 \%$ at 2 weeks and increased to $10.3 \pm 2.3 \%$ at 4 weeks. In h-hep-mice, the $\mathrm{R}_{\mathrm{HSC}}$ was approximately $5 \%$ for up to 7 weeks and significantly increased to $7.8 \pm 2.4 \%(P<0.01)$ at 11 weeks. The $R_{\text {HSC }}$ of $r$-hep-mice at 4 weeks was significantly higher than that of h-hep-mice at 11 weeks $(P<0.01)$.

\section{Discussion}

In this study, we compared the repopulation processes between $r$ - and h-hepatocytes in the livers of UPA/SCID mice and showed several physiologically significant differences. The r-hepatocytes rapidly replaced $\mathrm{m}$-hepatocytes to keep a normal $R_{L / B}$, suggesting a repopulation in a strictly regulated manner. The r-hepatocytes expressed TGFBR1/2 mRNAs at lower levels in the proliferation phase and then gradually increased expressions in the termination phase when m-HSCs actively expressed TGF- $\beta$. Moreover, Smad2/3 were translocated in $r$-hepatocyte nuclei, suggesting that TGF- $\beta / T$ TFBR/Smad signaling normally works as in the terminal phase of mouse liver regeneration.

In the chimeric animal h-hepatocytes were quite different from $r$-hepatocytes. They proliferated much slowly, requiring approximately four times longer to complete proliferation than r-hepatocytes. The resulting liver showed marked overgrowth compared with a normal m-liver. TGFBR2 and ACVR2A, and TGF- $\beta$ were not up-regulated in h-hepatocytes and m-HSCs of h-hep-mice, respectively, in the termination phase, indicating the absence of physiologically meaningful signaling between h-hepatocytes and $\mathrm{m}$-HSCs. The density of m-HSCs in h-hepatocyte colonies was lower than that in r-hepatocyte colonies even in the termination phase, which probably reflects the poor development of sinusoids in h-hep-mice, because the multiple hepatic plates would result in the lower volume of the space of Disse than in the liver with single hepatic plates. It has been reported that intimate signaling between hepatocytes and nonparenchymal cells plays an important role in the termination of liver regeneration. ${ }^{32}$ Thus, the failure of m-HSCs to express TGF- $\beta$ could be a cause of liver hyperplasia of h-hep-mice. However, it is appropriate to note here that other factors such as hepatocyte growth factor ${ }^{33}$ and bile acids ${ }^{34}$ might be involved in the observed hyperplasia.

In TGFBR2 knockout mice, partial hepatectomy resulted in a 1.2-fold increase beyond the normal liver weight because of a compensatory increase in activin A/ACVR2A signaling and persistent activity in the Smad pathway. ${ }^{20}$ Unlike in the study cited, the levels of ACVR2A mRNA and Smad proteins remained low through the experimental period in the present study with h-hep-mice. Thus, the lack of both TGF- $\beta$ and activin signaling may have been partly responsible for the observed overgrowth of hepatocytes. We did not observe any symptoms of carcinogenic transformation in h-hepatocytes (data not shown), although TGFBR2 ${ }^{35}$ and ACVR2 ${ }^{36}$ are putative tumor suppressors, suggesting a requirement for additional factor(s) for hepatocarcinogenesis.

Even in the absence of TGF- $\beta /$ TGFBR signaling, the transplanted $\mathrm{h}$-hepatocytes eventually terminated proliferation. The histological features of sinusoids and canaliculi in mouse liver repopulated by xenogeneic hepatocytes demonstrated that h-hepatocytes did not restore the normal arrangement of single hepatic plates in the resting phase of the liver, but they formed multiple hepatic plates seen in the regenerating liver. ${ }^{25,26}$ Thus, it is most likely that $\mathrm{h}$-hepatocytes eventually terminated the proliferation because of contact inhibition within the multiple hepatocyte layers. r-Hepatocytes also formed multiple hepatic plates in the proliferation phase but restored the normal structures of single cell plates along the portal-central axis in the termination phase. It seems that 
TGF- $\beta /$ TGFBR signaling is required for both the formation of single hepatic plates and the normal termination of liver growth. These apparently distinct events (liver growth termination and hepatic plate structuring) should be closely related at the molecular levels, because adhesion molecules such as E-cadherin and $\beta 1$-integrin are reported as the Smad2/3-mediated TGF- $\beta$ target genes in liver development. ${ }^{30}$ Our results demonstrated that Ecadherin uniformly exists on the hepatocyte surfaces in the normal h-liver, but its expression was quite low in substantial portions of the h-hepatocyte region in the h-hep-mouse liver. It is likely that this expression defect in the cell adhesion molecule results in abnormal hepatocyte plate arrangements. Loss of TGF- $\beta$ signaling in hhep-mice might be responsible for the maintenance of multicell-thick hepatic plates after the termination of liver repopulation in the h-hep-mouse livers.

There is the possibility that the observed hyperplasia of $\mathrm{h}$-hepatocytes is the result of a signaling failure between $\mathrm{m}$-cytokine ligands and the corresponding h-receptors. Recently, we showed that h-hepatocytes in h-hep-mice are growth hormone-deficient, because mouse growth hormone does not recognize the human growth hormone receptor of h-hepatocytes. ${ }^{37}$ However, we consider that h-hepatocytes would be able to respond to TGF- $\beta$ if the host $m$-HSCs secreted it, because there has been no report of species specificity between $\mathrm{h}$ - and $\mathrm{m}$-TGF- $\beta$. In the present study we clearly demonstrated the coincidence of lack of TGF- $\beta$ /TGFBR signaling with the hyperplasia of h-hepmouse liver. However, the direct causality between such signaling and the liver hyperplasia remains to be examined. It is well known that hepatocytes and stellate cells interact with each other through varieties of signaling molecules and together contribute to physiological and pathological changes of liver. Therefore, we conclude that the lack of or weak interaction between h-hepatocytes and $\mathrm{m}$-HSCs, which we have revealed at the histological and gene/protein expression levels, is responsible for the presently observed hyperplasia of h-hep-mouse liver.

Xenotransplantation, such as from pigs to humans, could potentially compensate for the lack of human organ and tissue donors. Our results indicate that, in addition to potential immunological rejection, the transplanted cells or tissues may fail to interact appropriately with the host environment. We propose that the h-chimeric mouse is a useful model for not only examining the mechanism of liver regeneration but also studying risks of xenotransplantation.

\section{Acknowledgments}

We thank Yasumi Yoshizane, Hiromi Kohno, Yoko Matsumoto, and Sanae Nagai for technical assistance and Dr. Masumi Yamada for helpful discussion and comments.

\section{References}

1. Heckel JL, Sandgren EP, Degen JL, Palmiter RD, Brinster RL: Neonatal bleeding in transgenic mice expressing urokinase-type plasminogen activator. Cell 1990, 62:447-456

2. Locaputo S, Carrick TL, Bezerra JA: Zonal regulation of gene expres- sion during liver regeneration of urokinase transgenic mice. Hepatology 1999, 29:1106-1113

3. Rhim JA, Sandgren EP, Degen JL, Palmiter RD, Brinster RL: Replacement of diseased mouse liver by hepatic cell transplantation. Science 1994, 263:1149-1152

4. Rhim JA, Sandgren EP, Palmiter RD, Brinster RL: Complete reconstitution of mouse liver with xenogeneic hepatocytes. Proc Natl Acad Sci USA 1995, 92:4942-4946

5. Dandri M, Burda MR, Gocht A, Török E, Pollok JM, Rogler CE, Will H, Petersen J: Woodchuck hepatocytes remain permissive for hepadnavirus infection and mouse liver repopulation after cryopreservation. Hepatology 2001, 34:824-833

6. Dandri M, Burda MR, Török E, Pollok JM, Iwanska A, Sommer G Rogiers X, Rogler CE, Gupta S, Will H, Greten H, Petersen J: Repopulation of mouse liver with human hepatocytes and in vivo infection with hepatitis B virus. Hepatology 2001, 33:981-988

7. Tateno C, Yoshizane Y, Saito N, Kataoka M, Utoh R, Yamasaki C Tachibana A, Soeno Y, Asahina K, Hino H, Asahara T, Yokoi T, Furukawa T, Yoshizato K: Near completely humanized liver in mice shows human-type metabolic responses to drugs. Am J Pathol 2004, 165:901-912

8. Meuleman P, Libbrecht L, De Vos R, de Hemptinne B, Gevaert K, Vandekerckhove J, Roskams T, Leroux-Roels G: Morphological and biochemical characterization of a human liver in an UPA-SCID mouse chimera. Hepatology 2005, 41:847-856

9. Emoto K, Tateno C, Hino H, Amano H, Imaoka Y, Asahina K, Asahara $\mathrm{T}$, Yoshizato $\mathrm{K}$ : Efficient in vivo xenogeneic retroviral vector-mediated gene transduction into human hepatocytes. Hum Gene Ther 2005, 16:1168-1674

10. Kam I, Lynch S, Svanas G, Todo S, Polimeno L, Francavilla A, Penkrot RJ, Takaya S, Ericzon BG, Starzl TE, Van Thiel DH: Evidence that host size determines liver size: studies in dogs receiving orthotopic liver transplants. Hepatology 1987, 7:362-366

11. Van Thiel DH, Gavaler JS, Kam I, Francavilla A, Polimeno L, Schade RR, Smith J, Diven W, Penkrot RJ, Starzl TE: Rapid growth of an intact human liver transplanted into a recipient larger than the donor. Gastroenterology 1987, 93:1414-1419

12. Francavilla A, Zeng Q, Polimeno L, Carr BI, Sun D, Porter KA, Van Thiel DH, Starzl TE: Small-for-size liver transplantation into large recipient: a model of hepatic regeneration. Hepatology 1994, 19:210-216

13. Nakamura T, Tomita $Y$, Hirai R, Yamaoka K, Kaji K, Ichihara A: Inhibitory effect of transforming growth factor- $\beta$ on DNA synthesis of adult rat hepatocytes in primary culture. Biochem Biophys Res Commun 1985, 133:1042-1050

14. Russell WE, Coffey RJ Jr., Ouellette AJ, Moses HL: Type $\beta$ transforming growth factor reversibly inhibits the early proliferative response to partial hepatectomy in the rat. Proc Natl Acad Sci USA 1988, 85:5126-5130

15. Zhang YQ, Kanzaki M, Mashima H, Mine T, Kojima I: Norepinephrine reverses the effects of activin A on DNA synthesis and apoptosis in cultured rat hepatocytes. Hepatology 1996, 23:288-293

16. Hu PP, Datto MB, Wang XF: Molecular mechanisms of transforming growth factor- $\beta$ signaling. Endocr Rev 1998, 19:349-363

17. Kumar A, Novoselov V, Celeste AJ, Wolfman NM, ten Dijke P, Kuehn MR: Nodal signaling uses activin and transforming growth factor- $\beta$ receptor-regulated Smads. J Biol Chem 2001, 276:656-661

18. Braun L, Mead JE, Panzica M, Mikumo R, Bell GI, Fausto N: Transforming growth factor $\beta$ mRNA increases during liver regeneration: a possible paracrine mechanism of growth regulation. Proc Natl Acad Sci USA 1988, 85:1539-1543

19. Romero-Gallo J, Sozmen EG, Chytil A, Russell WE, Whitehead R, Parks WT, Holdren MS, Her MF, Gautam S, Magnuson M, Moses HL, Grady WM: Inactivation of TGF- $\beta$ signaling in hepatocytes results in an increased proliferative response after partial hepatectomy. Oncogene 2005, 24:3028-3041

20. Oe S, Lemmer ER, Conner EA, Factor VM, Levéen P, Larsson J, Karlsson S, Thorgeirsson SS: Intact signaling by transforming growth factor $\beta$ is not required for termination of liver regeneration in mice. Hepatology 2004, 40:1098-1105

21. Hino H, Tateno C, Sato H, Yamasaki C, Katayama S, Kohashi T, Aratani A, Asahara T, Dohi K, Yoshizato K: A long-term culture of human hepatocytes which show a high growth potential and express 
their differentiated phenotypes. Biochem Biophys Res Commun 1999, 256:184-191

22. Seglen PO: Preparation of isolated rat liver cells. Methods Cell Biol 1976, 13:29-83

23. Utoh R, Tateno C, Yamasaki C, Hiraga N, Kataoka M, Shimada T, Chayama K, Yoshizato K: Susceptibility of chimeric mice with livers repopulated by serially subcultured human hepatocytes to hepatitis $\mathrm{B}$ virus. Hepatology 2008, 47:435-446

24. Livak KJ, Schmittgen TD: Analysis of relative gene expression data using real-time quantitative PCR and the $2^{-\Delta \Delta C T}$ method. Methods 2001, 25:402-408

25. Wack KE, Ross MA, Zegarra V, Sysko LR, Watkins SC, Stolz DB: Sinusoidal ultrastructure evaluated during the revascularization of regenerating rat liver. Hepatology 2001, 33:363-378

26. Martinez-Hernandez A, Delgado FM, Amenta PS: The extracellular matrix in hepatic regeneration. Localization of collagen types I, III, IV, laminin, and fibronectin. Lab Invest 1991, 64:157-166

27. Keppler D, Konig J: Hepatic canalicular membrane 5: expression and localization of the conjugate export pump encoded by the MRP2 (cMRP/cMOAT) gene in liver. FASEB J 1997, 11:509-516

28. Michalopoulos GK: Liver regeneration. J Cell Physiol 2007, 213: 286-300

29. Chari RS, Price DT, Sue SR, Meyers WC, Jirtle RL: Down-regulation of transforming growth factor beta receptor type I, II, and III during liver regeneration. Am J Surg 1995, 169:126-132
30. Weinstein M, Monga SP, Liu Y, Brodie SG, Tang Y, Li C, Mishra L, Deng CX: Smad proteins and hepatocyte growth factor control parallel regulatory pathways that converge on $\beta 1$-integrin to promote normal liver development. Mol Cell Biol 2001, 21:5122-5131

31. Cassiman D, Libbrecht L, Desmet V, Denef C, Roskams T: Hepatic stellate cell/myofibroblast subpopulations in fibrotic human and rat livers. J Hepatol 2002, 36:200-209

32. Koniaris LG, McKillop IH, Schwartz SI, Zimmers TA: Liver regeneration. J Am Coll Surg 2003, 197:634-659

33. Patijn GA, Lieber A, Schowalter DB, Schwall R, Kay MA: Hepatocyte growth factor induces hepatocyte proliferation in vivo and allows for efficient retroviral-mediated gene transfer in mice. Hepatology 1998 , 28:707-716

34. Huang W, Ma K, Zhang J, Qatanani M, Cuvillier J, Liu J, Dong B, Huang X, Moore DD: Nuclear receptor-dependent bile acid signaling is required for normal liver regeneration. Science 2006, 312:233-236

35. Derynck R, Akhurst RJ, Balmain A: TGF- $\beta$ signaling in tumor suppression and cancer progression. Nat Genet 2001, 29:117-129

36. Jeruss JS, Sturgis CD, Rademaker AW, Woodruff TK: Down-regulation of activin, activin receptors, and Smads in high-grade breast cancer. Cancer Res 2003, 63:3783-3790

37. Masumoto N, Tateno C, Tachibana A, Utoh R, Morikawa Y, Shimada $\mathrm{T}$, Momisako H, Itamoto T, Asahara T, Yoshizato K: GH enhances proliferation of human hepatocytes grafted into immunodeficient mice with damaged liver. J Endocrinol 2007, 194:529-553 